\title{
Comparative study of salicylic acid contents in young wheat and rice plants and their anticancer activities in HepG2 and Caco-2 cells
}

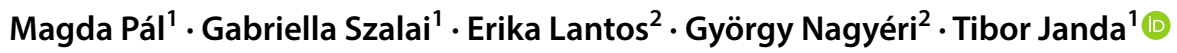

Received: 27 February 2020 / Accepted: 15 June 2020 / Published online: 24 June 2020

(c) The Author(s) 2020

\begin{abstract}
Some recent results reported that aspirin (acetylsalicylic acid) had a positive effect on the treatment of certain types of cancer. However, the results cannot be generalized and it is not always clear whether it is a direct anticancer effect or a general health effect. Since plants produce different amounts of salicylic acid, we have sought a relationship between the salicylic acid content of some plant extracts and their anticancer activity. Growing of wheat and rice plants were carried out under controlled conditions. The salicylic acid content was determined by high-performance liquid chromatography. The viability and cell cycle assays were performed on HepG2 and Caco-2 cell lines. Despite the high content of salicylic acid, the extracts from rice plants did not show significant anticancer activity. In spite of the low salicylic acid content, the positive effect of wheat germ was confirmed in both tests. There is no direct relationship between the salicylic acid content of the plant extracts and their anticancer activity. However, it has been proven that young wheat germ is more effective than mature leaf.
\end{abstract}

Keywords Anticancer activity Plant extract $\cdot$ Plant seedlings $\cdot$ Salicylic acid

\section{Introduction}

The risk of developing cancer is estimated to be around $40 \%$ worldwide, a trend that continues to increase, particularly in developing countries [14]. Around 3.2 million new cases occur each year in Europe, resulting in around 1.7 million deaths [7]. Some results indicate that long-term use of aspirin (acetylsalicylic acid) may reduce the risk of certain types of cancer, especially gastrointestinal cancers. In particular, studies in animal models suggest that the effect is at least in part related to inhibition of cyclooxygenase enzymes and reduction in prostaglandin production [2]. Recent clinical studies have shown positive effects not only in animals but also in humans [10,20]. Other results, however, have shown that there is no close association between aspirin use and risk of prostate cancer mortality [26], but that aspirin use may provide longer survival period for patients before and after diagnosis of prostate cancer, highlighting the

Tibor Janda

janda.tibor@agrar.mta.hu

1 Department of Plant Physiology, Agricultural Institute, Centre for Agricultural Research, Brunszvik u. 2, Martonvásár 2462, Hungary

2 SOFTFLOW Ltd., Kedves u. 20, Pécs 7628, Hungary importance of preventing comorbidity in prostate cancer among its survivors [25].

Nowadays, it is becoming increasingly common for people to prefer natural products over synthetic medicines. In addition to this kind of "fashion" in the developed world, such products are especially of great importance in the health care of developing countries.

The active ingredient in aspirin is salicylic acid, which is found in very large amounts in various forms in certain plants. The most well-known example is the willow bark, which has been used since antiquity for its antipyretic and anti-inflammatory action. The word salicylic acid itself can be traced back to the Latin name of the willow, Salix.

Early results showed that salicylic acid as a plant hormone plays an important role in disease resistance and programmed cell death. Infection of plants with pathogen induces the biosynthesis and accumulation of salicylic acid. Studies have shown that increased salicylic acid accumulation may also be associated with a hypersensitive reaction. Its role has been confirmed in both local and systemic acquired resistance [5, 19]. In plants, NPR1 and its orthologs, NPR3 and NPR4 are known as receptors for salicylic acid $[6,8]$. In addition to developing resistance to biotic stressors, the use of exogenous salicylic acid has been shown to be effective against various abiotic stresses. Most 
of these effects were due to an induction of the antioxidant systems $[9,12,22]$.

There are significant variations in the salicylic acid content of each plant species, and there are differences between the individual organs of the plant and the state of development, too. In addition, the salicylic acid content of plants can be significantly increased under certain stressors, either the above mentioned biotic effects or abiotic factors, especially heavy metal contamination [17]. Rice leaves usually can be characterized with extremely high salicylic acid contents. While in most other crops, including cereals, such as wheat, the salicylic acid content is generally below $1 \mu \mathrm{g} / \mathrm{g}$ fresh weight, it is often higher than 30-40 $\mu \mathrm{g} / \mathrm{g}$ fresh weight in various rice varieties [18]. The exact role of this high salicylic acid content is still unknown. It is assumed that SA plays role in maintaining redox balance and protecting against oxidative stress [24].

Apoptosis and necrosis are two different forms of cell death. Apoptosis is accompanied by reduction in cellular volume, chromatin condensation, and nuclear fragmentation. Apoptosis is also characterized by maintenance of plasma membrane integrity until the final stages. Necrotic cell death is accompanied by gain in cell volume, swelling of organelles, plasma membrane rupture and subsequent loss of intracellular contents. Dying cells undergo a process that is reversible until a first irreversible phase occurs, characterized primarily by caspase activation [15].

Since different plant species produce very different levels of salicylic acid, we hypothesized that if salicylic acid had a significant anticancer effect, the salicylic acid content of the extracts from certain different plant species or organs could also be positively correlated with their anticancer effects. For the present study, HepG2 and Caco-2 cells were chosen as liver and colorectal cancers are the most common widespread cancer types causing high mortality rate. The used cell lines are widely applied in vitro cell culture models, as the gastrointestinal tract is an important route of exposure for toxic food ingredients and beneficial food supplements as well.

\section{Materials and methods}

\section{Plant growth conditions}

Mv Emese winter wheat (Triticum aestivum L.) and Janka japonica rice (Oryza sativa L.) varieties were used for the experiments. The seeds were germinated on filter paper moistened with distilled water, in case of wheat for 3 days in the dark at $22{ }^{\circ} \mathrm{C}$, in the case of rice for 1 day at $37^{\circ} \mathrm{C}$ and then for another 3 and 6 days at $27^{\circ} \mathrm{C}$ in the dark. For the cultivation of adult plants, the plants were grown in hydroponic solutions at $22 / 20{ }^{\circ} \mathrm{C}$ for wheat [17] and for rice at
28/26 ${ }^{\circ} \mathrm{C}$ [18] in PGR-15 plant growth chamber (Conviron Ltd, Winnipeg, Canada) at $250 \mu \mathrm{mol} / \mathrm{m}^{2} \mathrm{~s}$ photon flux density with $16 / 8 \mathrm{~h}$ light/dark periods. Samples for determination of salicylic acid contents from the shoots and roots were taken 3 days after germination in Mv Emese wheat, and 4 and 7 days after germination, and the youngest fully developed leaves from the 21-day-old Janka rice plants. At the first time points, with a 1-day shift, the developmental stages of wheat and rice plants were similar.

\section{Determination of salicylic acid content}

Wheat or rice plant samples ( 0.5 or $0.2 \mathrm{~g}$, respectively) were homogenized in liquid nitrogen and extracted with methanol according to Pál et al. [17]. For the measurement Waterstype high-performance liquid chromatography (HPLC) coupled with fluorescence detector (W2690 modul with W474 scanning fluorescence detector, WATERS, Milford, MA, USA) was used. After separation on a $4 \mu \mathrm{m}$ particle size $150 \times 4.6 \mathrm{~mm}$ Synergi 4u Fusion-RP 80A (Phenomenex, Inc. California, USA) analytical column the identification and quantitative analysis of SA was performed at $305 \mathrm{~nm}$ excitation and $407 \mathrm{~nm}$ emission wavelengths as it was previously described in Pál et al. [17]. Measurement data were evaluated using the Millenium32 program (WATERS, Milford, MA, USA). The detailed description of the HPLC analysis was described by Janda et al. [13].

\section{Cell culturing}

Previously adopted and cryopreservated HepG2 hepatocarcinoma cells $\left(\mathrm{ATCC}^{\circledR} \mathrm{HB}-8065^{\mathrm{TM}}\right.$ ) and Caco-2 colorectal adenocarcinoma cells (ATCC ${ }^{\circledR}$ HTB-37TM) with the same copies/cell aliquots with low passage number of the cells were used in the experiments. Standard cell culture conditions and the ATCC recommendations were applied for cell cultures. Cells were cultured in Petri Dishes (BD, 353,003) or later, in flasks $\left(75 \mathrm{~cm}^{2}\right.$, Greiner, 658,170$)$ and kept in a humidified atmosphere of $5 \% \mathrm{CO}_{2}$ in air at $37^{\circ} \mathrm{C}$.

\section{Cell exposures}

HepG2 and Caco- 2 cells were seeded onto $2 \times 2$ 96-well tissue culture-treated plates in final volume of $100 \mu \mathrm{L}$ medium. After their adherence to the plate, the cells were treated for $48 \mathrm{~h}$ with three doses (D1-D3) of the seedling extracts. $1 \mathrm{~g}$ of plant tissue was homogenized in liquid nitrogen, after than the homogenate was centrifuged by micro-SpinFilter tubes (Micro-Spin-Filter Tubers, Fisher Scientific; $0.45 \mu \mathrm{m}$ ) with $10,000 \mathrm{~g}$ at $4{ }^{\circ} \mathrm{C}$ for $10 \mathrm{~min}$. After this, extracts were centrifuged, and the supernatants were $10 \times$ diluted with the medium and sterile-filtered $(0.45 \mu \mathrm{m}$ syringe filter $)$ before further dilutions. $10 \times(\mathrm{D} 1), 20 \times(\mathrm{D} 2)$ and $40 \times$ 
(D3) dilutions were used for the treatments, except for the 3 -week-old Janka rice extract from which low amount was available, therefore $20 \times, 40 \times$ and $80 \times$ dilutions could be made. The extracts were added in $100 \mu \mathrm{L}$ volume to the wells containing the cells. Absolute control (AC, exposed to RPMI, Roswell Park Memorial Institute 1640 medium) and positive/salicylic acid controls (containing 0.5-50 $\mu \mathrm{g}$ / $\mathrm{mL}$ ) were run in parallel.

\section{Cell analysis using a high content screening (HCS) system}

The living cells were observed under transmitted light at 0 day, 1 day and 2 days of treatment on Olympus Scan^R HCS system. At the endpoint ( 2 days) viability test and cell cycle analysis were performed for assessing the extracts effects on the cells. For the cell viability test the cells were washed with 0.01 M PBS (phosphate buffer saline; $\mathrm{pH} 7.4$ ). Pre-titrated $(1.6 \mu \mathrm{g} / \mathrm{mL}$ in PBS) HOECHST nuclear stain was added to each well and the cells were incubated for $10 \mathrm{~min}$ at room temperature, protected from the light. Propidium iodide $(2 \mu \mathrm{g} / \mathrm{mL}$ in PBS) was added to each well and incubated for further $10 \mathrm{~min}$. The cells were analysed on the HCS microscope ( 9 image fields taken/well, $10 \times$ objective magnification, O.M.) within $1 \mathrm{~h}$ after the staining procedure. Propidium iodide enters only the dead cells, while HOECHST stains all the nuclei (live and dead cells) with higher fluorescent signals on cells undergoing apoptosis and dead cells. Thus the intact live and dead cells, and those which are undergoing apoptosis can be distinguished according to their different staining characteristics.

Cell cycle analyses were carried out using Propidium iodide DNA staining. The cells were washed with $0.01 \mathrm{M}$ PBS (pH 7.4). Fixation/permeabilization of the cells was done with ice cold $70 \%$ Ethanol, by incubation at $4{ }^{\circ} \mathrm{C}$ for $1 \mathrm{~h}$. Ethanol was washed out with PBS buffer and the cells were stained for DNA using pre-titrated $(80 \mu \mathrm{g} / \mathrm{mL})$ propidium iodide, $0.1 \mu \mathrm{g} / \mathrm{mL}$ RNase and $1 \%$ Triton X solution in PBS buffer for $1 \mathrm{~h}$ at room temperature, protected from the light. Propidium iodide fluorescent signal was acquired (9 image fields taken/well, $10 \times$ O.M.) and analysed on histograms (histogram of propidium iodide positive cells having on $\mathrm{x}$-axis the fluorescent signal intensity recorded on cells and on $y$-axis the cell count). The first peak on the histogram corresponds to G0/G1 phase and the second peak corresponds to $\mathrm{G} 2 / \mathrm{M}$ phase, between them the cells are in $\mathrm{S}$ phase. The cells detected before the first peak are cells undergoing apoptosis (sub G0/G1). To detect exactly the cells in $\mathrm{S}$ phase other dyes (as 5'-bromo-2-deoxyuridine, BrdU) would be needed. With the applied method we can count the cells undergoing apoptosis, G0/G1/early S phase cells and late $\mathrm{S} / \mathrm{G} 2 / \mathrm{M}$ cells. The applied method enabled us to count the sub G0/G1 cells (with fragmented DNA most frequently due to apoptosis [4], G0/G1/early $\mathrm{S}$ phase cells and late S/G2/M phase cells. For simplicity, we use apoptotic (cells undergoing apoptosis), G0/G1 and G2/M for the above-mentioned cell populations further.

\section{Statistical analysis}

The results obtained represent the mean of 3-3 independent measurements for both salicylic acid content and anticancer activity. The data for salicylic acid contents were statistically evaluated using the standard deviation in Microsoft Excel and significant differences using SPSS 16.0. Significant differences between the control and salicylic acid or plant extract treatments in the viability and cell cycle assays were determined using a the two-sample $t$ test method.

\section{Results}

\section{Salicylic acid contents in cereals}

In the first experiment, the salicylic acid contents were measured both in the shoots and roots, 3 days after germination in Mv Emese wheat, and 4 and 7 days after germination, in addition in 21-day-old Janka rice plants (Table 1). The
Table 1 The free and bound salicylic acid contents (ng $\mathrm{SA} / \mathrm{g}$ fresh weight \pm standard deviation) of 4, 7 and 21 dayold Janka rice and 3 or 22 dayold Mv Emese wheat shoots and root

\begin{tabular}{lccccc}
\hline & Janka 4 days & Janka 7 days & Janka 21 days & Mv Emese 3 days & Mv Emese 22 \\
\hline Shoot & & & & & \\
Free & $50.4 \pm 8.1 \mathrm{~b}$ & $517 \pm 94.7 \mathrm{c}$ & $14,002 \pm 332 \mathrm{e}$ & $13.0 \pm 3.2 \mathrm{a}$ & $\sim 13$ \\
Bound & $24.4 \pm 5.7 \mathrm{a}$ & $59.4 \pm 5.1 \mathrm{~b}$ & $1970 \pm 150 \mathrm{~d}$ & $15.0 \pm 1.6 \mathrm{a}$ & $\sim 130$ \\
Root & & & & \\
Free & $28.8 \pm 5.8 \mathrm{~b}$ & $63.2 \pm 1.15 \mathrm{c}$ & $83.7 \pm 33.7 \mathrm{abc}$ & $9.80 \pm 3.58 \mathrm{a}$ & $\mathrm{nd}$ \\
Bound & $30.6 \pm 9.7 \mathrm{~b}$ & $90.1 \pm 17.6 \mathrm{c}$ & $160 \pm 58.2 \mathrm{bc}$ & $8.34 \pm 4.5 \mathrm{a}$ & $\mathrm{nd}$ \\
\hline
\end{tabular}

Different letters indicate statistically significant differences in the SA contents, separately in the shoots and roots at $P<0.05$ level

nd not determined

${ }^{\mathrm{a}} \mathrm{Mv}$ Emese 22 days data are calculated from a previous study [11] 
salicylic acid data show that, as expected, the young rice germs of similar maturity contained significantly more salicylic acid than wheat. Later, in rice, the salicylic acid content of the evolving shoot increased further, and increased at 7 days compared to 4 days (Table 1). Earlier data of the same wheat variety of the similar age and adult leaf showed only 10-15 ng/g fresh weight free and 130 ng/g FW bound salicylic acid contents [11]. There was no such difference in the root (Fig. 1b). Based on these data, 4 samples with significant differences in salicylic acid content were selected: 3-day-old Mv Emese wheat and 7-day Janka rice germs, and 3-week-old Mv Emese and 3-week Janka leaves based on the previous measurements [11].

\section{Investigation of anticancer effects of plant extracts}

The percentage of intact live HepG2 cells in the samples treated with 3-day-old Mv Emese wheat germ extract was drastically reduced at all dilutions $(10 \times-40 \times)$ (Fig. 1a). In these samples, dead cells dominated, accounting for $>70 \%$ of the cells. The percentage of cells undergoing apoptosis increased approximately fourfold compared with untreated controls. For the 7-day-old rice germ, a slight (about 10\%) dose-dependent decrease in viability was observed in the $10 \times$ and $20 \times$ diluted samples. In parallel, the percentage of cells undergoing apoptosis and dead cells increased in a dose-dependent manner: a greater effect was observed when
Fig. 1 Results of HepG2 cell viability assay (a) and cell cycle assay (b) using various dilutions of salicylic acid (SA) and plant extracts. Apoptotic data refers to cells undergoing apoptosis. *Next to each column elements indicate significant differences at $P<0.05$ as compared to control
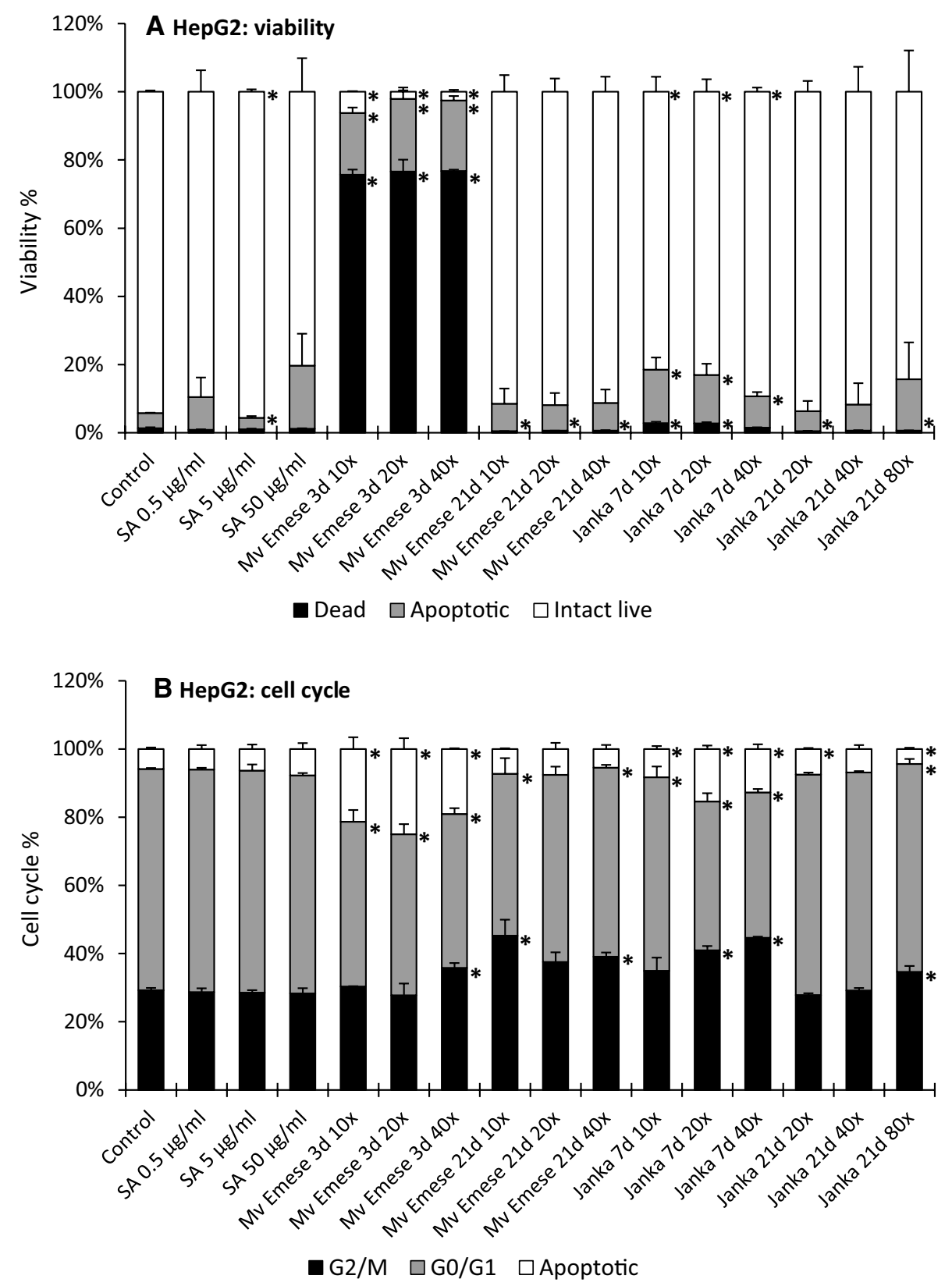
the extract was less diluted. In the case of Janka rice and Mv Emese wheat at 3 weeks, only a small amount of apoptosis was observed compared to the control. Even at the highest concentration used in the experiment $(50 \mu \mathrm{g} / \mathrm{mL})$, pure salicylic acid had only a minor effect on the viability of HepG2.

Caco-2 cells showed the same effects as HepG2 cells; that is, the 3-day-old wheat germ extract had the most pronounced effect on cell viability (Fig. 2a). The percentage of dead cells in the samples treated with the leaf extracts from the 3-week-old wheat plants decreased and consequently more intact live cells were detected in these samples. Salicylic acid treatments did not affect the viability of Caco-2 cells in our experiment.
Regarding cell cycle effects, the percentage of G0/G1 cells and the percentage of cells undergoing apoptosis increased in HepG2 cells treated with 3-day-old wheat germ extract (Fig. 1b). In addition, the number of Caco-2 cells undergoing apoptosis was also increased in the $10 \times$ diluted samples (Fig. 2b). When treated with 7-dayold rice germ extracts, the percentage of HepG2 cells increased in the $\mathrm{G} 2 / \mathrm{M}$ phase compared to the untreated control. The same effect was observed on HepG2 cells treated with adult wheat leaf extracts (Fig. 1b) and on Caco-2 resulted in fewer cells in G0/G1 (Fig. 2b). Pure salicylic acid solution did not affect the cell cycle of HepG2 cells at any dilution used.
Fig. 2 Result of Caco-2 cell viability test (a) and cell cycle assay (b) using various dilutions of salicylic acid solution (SA) and plant extracts. Apoptotic data refers to cells undergoing apoptosis. *Next to each column elements indicates significant differences at $P<0.05$ as compared to control
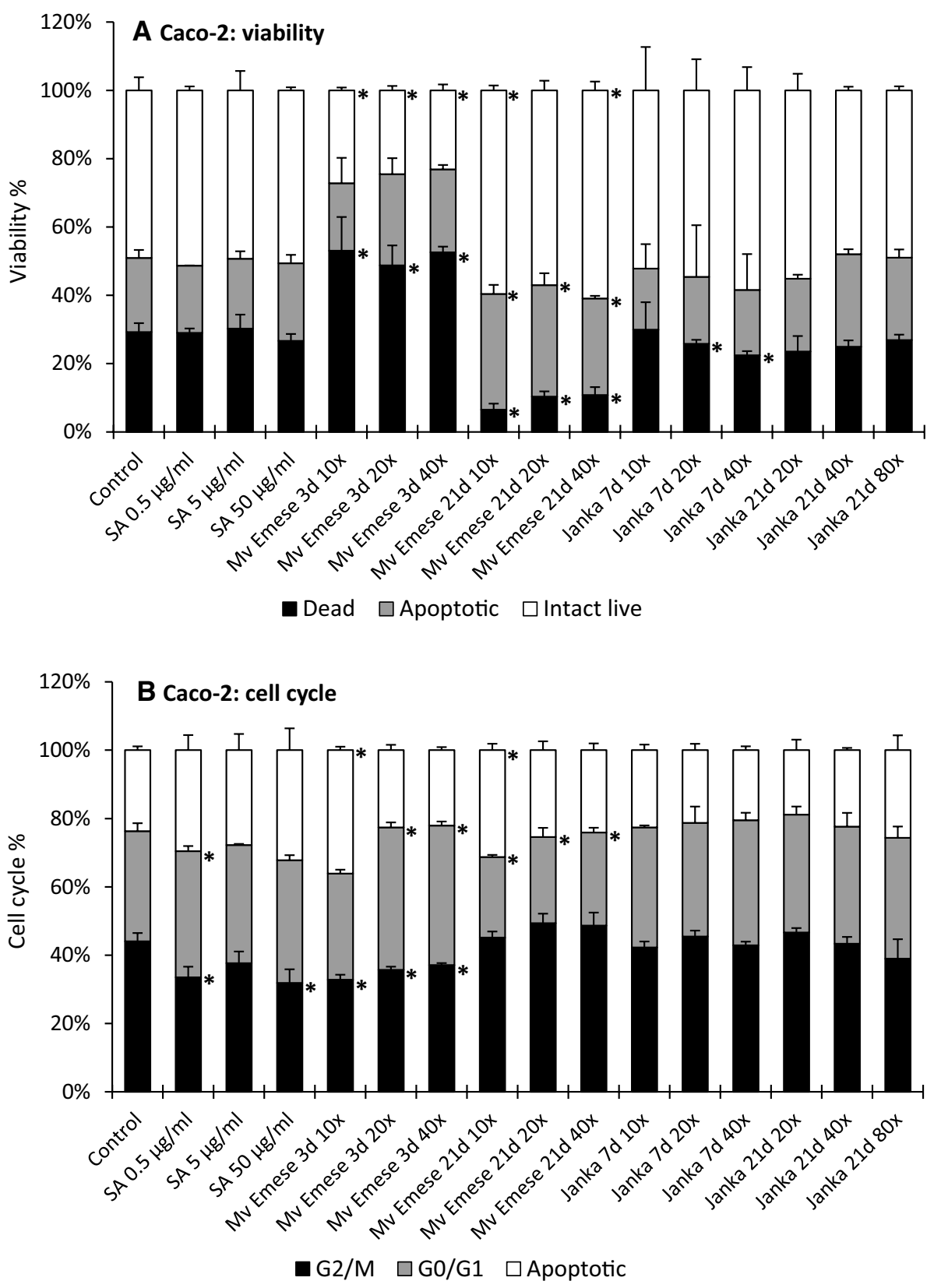


\section{Discussion}

In the present experiments, we tested the anticancer activity of plant extracts from certain cereals (wheat and rice) in an in vitro test system using different cell models. We found that young wheat germ extract strongly influenced the survival of both HepG2 and Caco-2 cells, and this extract had the highest cytotoxicity. A well-known anticancer drug, cisplatin, reduced HepG2 cell viability by $50 \%$ when applied for $48 \mathrm{~h}$ at $5 \mu \mathrm{g} / \mathrm{mL}$ (data not shown). In the present experiment, wheat germ extract reduced the viability of HepG2 cells by more than $90 \%$, indicating that it may contain some effective anticancer compounds (mixtures).

The other extracts had a much smaller effect on cell viability, and in many cases the effects were not significant. Regarding the effects on HepG2 cell cycle, the 3-dayold wheat germ extract application resulted in a decrease in the G0/G1/early $S$ cell population and consequently an increase in the number of sub G0/G1 (mainly apoptotic) cells. Treatment with young rice germ and wheat leaf extract led to increased cell accumulation in the late $\mathrm{S} /$ $\mathrm{G} 2 / \mathrm{M}$ phase. In our experiments, the effect of $0.5-50 \mu \mathrm{g} /$ $\mathrm{mL}$ salicylic acid was not outstanding, although in this case either the selected doses could be too low, or the exposure applied was inadequate. According to our results there is no correlation between the effect of salicylic acid and the plant extract, considering that all extracts contained less than $50 \mu \mathrm{g} / \mathrm{mL}$ salicylic acid. Thus, it can be concluded that the anticancer effect of the young wheat germ extract is not related to its salicylic acid content. Other components, or possibly a mixture of components, may have caused the resulting effects, which need further investigation. It is possible that another type of experimental setup (e.g. longer incubation, higher target doses, etc.) may also result in a more effective anticancer effect on the cells. However, this does not affect the present conclusion.

The positive anticancer effects of wheat germ have been proven by several experiments. On the one hand, this is the main active ingredient of certain already commercially available products, and on the other hand, the direct lymphomacid activity of the protein fraction of fermented wheat germ has been described without toxic effects even at the highest doses tested [1]. It must also be mentioned that anticancer activity in a human being may also be manifested at the level of the immune system. This process may also be affected by SA or its certain derivatives.

It should be noted that plants do not synthesize salicylic acid for purposes of human medicine. Although its role has been recognized in recent decades, its exact mechanism of action is still not fully understood. There are three major routes to salicylic acid synthesis in plants [16]. Two of these paths start from the phenylpropanoid pathway. Here, phenylalanine is converted to cinnamic acid by phenylalanine ammonia lyase, and then, depending on whether a decarboxylation step or a hydroxylation step occurs, the two pathways are separated. When the side chain of cinnamic acid is first carboxylated, benzoyl glucose is formed that, after hydroxylation, becomes salicylic acid. When cinnamic acid is first hydroxylated, ortho-coumaric acid, also known as ortho-hydroxy-cinnamic acid, and after decarboxylation, salicylic acid is formed [16]. Synthesis via shikimic acid was first discovered in microorganisms and later in plants under biotic stress, where 3-enolpyruvylshikimate-5-phosphate is converted to chorismate by chorismate synthase. This compound is converted to its isoform isochorismate by isochorismate synthase, which is a precursor of salicylic acid in this pathway [23]. The role of the shikimic acid pathway in the synthesis of salicylic acid has also been demonstrated in young pea plants [21]. It is also important to note that salicylic acid-related compounds, precursors, may have similar effects to salicylic acid in plants. These effects also require further studies in plants, and their potential therapeutic use is not fully understood. Thus, it is not excluded that an effective anticancer component should be sought among salicylic acidrelated compounds.

\section{Conclusion for future biology}

In the present study, salicylic acid content did not correlate with anticancer activity. It must also be mentioned that wheat germ extract may contain a great number of active ingredients other than SA or its derivatives. For example, in another experimental system, a mixture of resveratrol, quercetin and gallic acid, at relative concentrations similar to those contained in most red wines potentiated sub-inhibitory concentrations of aspirin in platelet aggregation [3]. So the interactions between the active compounds should also be taken into account. The effect of the pure salicylic acid solution was not significant either, so not an inhibitory effect caused by some other compounds also present in the sample, altered the results. These results confirm that salicylic acid and aspirin are expected to be less effective in these type of cancers. However, the anticancer effect of wheat germ with low salicylic acid content was proven, but this effect has already been reduced in adult leaves.

Acknowledgements Open access funding provided by ELKH Centre for Agricultural Research.

Authors' contributions M.P. involved in plant cultivation, HPLC analysis, and preparing diagrams. G. Sz. involved in participation in conducting the experiment, completing the text, editing tables and figures. E.L. 
and Gy.N. involved in testing and evaluation of anticancer effect, and writing related parts of results. T.J. involved in the literature review, experiment design, writing the paper, drawing diagrams and tables. The manuscript has been read, reviewed and approved by all authors.

Funding This research was supported by the National Research, Development and Innovation Office (K124430 project).

\section{Compliance with ethical standards}

Conflict of interest We have no conflict of interest.

Open Access This article is licensed under a Creative Commons Attribution 4.0 International License, which permits use, sharing, adaptation, distribution and reproduction in any medium or format, as long as you give appropriate credit to the original author(s) and the source, provide a link to the Creative Commons licence, and indicate if changes were made. The images or other third party material in this article are included in the article's Creative Commons licence, unless indicated otherwise in a credit line to the material. If material is not included in the article's Creative Commons licence and your intended use is not permitted by statutory regulation or exceeds the permitted use, you will need to obtain permission directly from the copyright holder. To view a copy of this licence, visit http://creativecommons.org/licenses/by/4.0/.

\section{References}

1. Barisone GA, O'Donnell RT, Ma Y, Abuhay MW, Lundeberg K, Gowda S, Tuscano JM (2018) A purified, fermented, extract of Triticum aestivum has lymphomacidal activity mediated via natural killer cell activation. PLoS ONE 13:e0190860

2. Chan AT, Ogino S, Fuchs CS (2007) Aspirin and risk of colorectal cancer in relation to expression of COX-2. N Engl J Med 356:2131-2142

3. Crescente M, Jessen G, Momi S, Höltje HD, Gresele P, Cerletti C, de Gaetano G (2009) Interactions of gallic acid, resveratrol, quercetin and aspirin at the platelet cyclooxygenase- 1 level. Functional and modelling studies. Thromb Haemost 102:336-346

4. Crowley LC, Chojnowsky G, Waterhouse NJ (2016) Measuring the DNA content of cells in apoptosis and at different cell cycle stages by propidium iodide staining and flow cytometry. Cold Spring Harb Protoc. https://doi.org/10.1101/pdb.prot087247

5. Delaney TP, Friedrich L, Ryals JA (1995) Arabidopsis signal transduction mutant defective in chemically and biologically induced disease resistance. Proc Natl Acad Sci USA 92:6602-6606

6. Després C, Chubak C, Rochon A, Clark R, Bethune T, Desveaux D, Fobert PR (2003) The Arabidopsis NPR1 disease resistance protein is a novel cofactor that confers redox regulation of DNA binding activity to the basic domain/leucine zipper transcription factor TGA1. Plant Cell 15:2181-2191

7. Ferlay J, Autier P, Boniol M, Heanue M, Colombet M, Boyle P (2007) Estimates of the cancer incidence and mortality in Europe in 2006. Ann Oncol 18:581-592

8. Fu ZQ, Yan S, Saleh A, Wang W, Ruble J, Oka N, Mohan R, Spoel SH, Tada Y, Zheng N, Dong X (2012) NPR3 and NPR4 are receptors for the immune signal salicylic acid in plants. Nature 486:228-232

9. Horváth E, Szalai G, Janda T (2007) Induction of abiotic stress tolerance by salicylic acid signaling. J Plant Growth Reg 26:290-300
10. Hurwitz LM, Joshu CE, Barber JR, Prizment AE, Vitolins MZ, Jones MR, Folsom AR, Han M, Platz EA (2019) Aspirin and non-aspirin NSAID use and prostate cancer incidence, mortality, and case fatality in the atherosclerosis risk in communities study. Cancer Epidemiol Biomark Prev 28:563-569

11. Janda T, Szalai G, Leskó K, Yordanova R, Apostol S, Popova LP (2007) Factors contributing to enhanced freezing tolerance in wheat during frost hardening in the light. Phytochemistry 68:1674-1682

12. Janda T, Szalai G, Tari I, Páldi E (1999) Hydroponic treatment with salicylic acid decreases the effects of chilling injury in maize (Zea mays L.) plants. Planta 208:175-180

13. Janda T, Lejmel MA, Molnár AB, Majláth I, Pál M, Nguyen QT, Nguyen NT, Le VN, Szalai G (2020) Interaction between elevated temperature and different types of Na-salicylate treatment in Brachypodium dystachion. PLoS ONE 15:e0227608

14. Jemal A, Center MM, DeSantis C, Ward EM (2010) Global patterns of cancer incidence and mortality rates and trends. Cancer Epidemiol Biomark Prev 19:1893-1907

15. Kroemer G, Galluzzi L, Vandenabeele P, Abrams J, Almemri ES, Baehrecke EH, Blagosklonny MV, El-Deiry WS, Golstein P, Green DR, Hengartner M, Knight RA, Kumar S, Lipton SA, Malorni W, Nunez G, Peter ME, Tschopp J, Yuan J, Piacentini M, Zhivotovsky B, Melino G (2009) Classification of cell death: recommendation of the Nomenclature Committee on Cell Death. Cell Death Differ 16:3-11

16. Métraux JP (2002) Recent breakthroughs in the study of salicylic acid biosynthesis. Trends Plant Sci 7:332-334

17. Pál M, Horváth E, Janda T, Páldi E, Szalai G (2005) Cadmium stimulates the accumulation of salicylic acid and its putative precursors in maize (Zea mays L.) plants. Physiol Plant 125:356-364

18. Pál M, Kovács V, Szalai G, Soós V, Ma X, Liu H, Mei H, Janda T (2014) Salicylic acid and abiotic stress responses in rice. J Agron Crop Sci 200:1-11

19. Raskin I (1992) Role of salicylic acid in plants. Annu Rev Plant Physiol Plant Mol Biol 43:439-463

20. Rothwell PM, Fowkes FG, Belch JF, Ogawa H, Warlow CP, Meade TW (2011) Effect of daily aspirin on long-term risk of death due to cancer: analysis of individual patient data from randomised trials. Lancet 377:31-41

21. Szalai G, Horgosi S, Soós V, Majláth I, Balázs E, Janda T (2011) Salicylic acid treatment of pea seeds induces its de novo synthesis. J Plant Physiol 168:213-219

22. Szalai G, Pál M, Árendás T, Janda T (2016) Priming seed with salicylic acid increases grain yield and modifies polyamine levels in maize. Cereal Res Commun 44:537-548

23. Wildermuth MC, Dewdney J, Wu G, Ausubel FM (2001) Arabidopsis defence against pathogens requires salicylic acid synthesized isochorismate synthase. Nature 414:562-565

24. Yang Y, Qi M, Mei C (2004) Endogenous salicylic acid protects rice plants from oxidative damage caused by aging as well as biotic and abiotic stress. Plant J 40:909-919

25. Zhou CK, Daugherty SE, Liao LM, Freedman ND, Abnet CC, Pfeiffer R, Cook MB (2017) Do aspirin and other NSAIDs confer a survival benefit in men diagnosed with prostate cancer? A pooled analysis of NIH-AARP and PLCO cohorts. Cancer Prev Res 10:410-420

26. Zhou J, Xia S, Li T, Liu R (2019) Could aspirin be a lifesaver for prostate cancer patients in prostate cancer-specific mortality? An update systematic review and meta-analysis. BMC Cancer 19:1186 